\title{
THE DISTRIBUTION OF THE COMMON HAMSTER (CRICETUS CRICETUS) IN WESTERN UKRAINE
}

\author{
Zofia Korbut ${ }^{1}$, Mikhail Yu. Rusin ${ }^{2}$, Agata Banaszek ${ }^{1}$ \\ 1 University of Białystok, Institute of Biology, Świerkowa 20B, \\ 15-950 Białystok, Poland \\ ${ }^{2}$ I.I. Schmalhausen Institute of Zoology NASU, B. Khmelnitskogo 15, \\ 01601 Kiev, Ukraine
}

\begin{abstract}
The aim of this study was to determine the current range of the common hamster (Cricetus cricetus) in western Ukraine by checking the points of occurrence known from literature, personal reports and museum collections. According to Rusin et al. (2013) the common hamster was reported from 23 localities grouped in 12 areas in 7 oblasts of Western Ukraine. In total, we confirmed eight areas of hamster occurrence from Rusin et al. (2013) and found one new locality. The highest densities of the common hamster occured around Hrymailiv, Ternopol oblast and Halych, IvanoFrankovsk oblast. The areas located in the vicinity of Lutsk in Volyn oblast, Chernovtsy and between Sambir and Old Sambir in Lvov oblast represent medium density populations. Low and very low densities were found in areas close to Lvov and Kamieniec Podolski, and Khmelnitskiy oblast. In general, it can be stated that the Volyn Upland and Podolia are still inhabited by the common hamster. Moreover, habitat conditions that support the existence of the common hamster and possibilities of contact with hamster populations from neighboring countries are also discussed in this paper.
\end{abstract} lineages

Key words: endangered species, distribution range, contact zone, phylogeographic

\section{INTRODUCTION}

The common hamster (Cricetus cricetus) is a rodent species characterized by a large Eurasian range extending from the river Yenisei in Russia, to Central and Western Europe where it forms isolated populations in Belgium, the Neth-

Contribution of 26th Meeting of the International Hamster Workgroup, 15-17th November 2013, Poznań, Poland 
erlands and France. The European northern boundary of this species is spread between $45^{\circ}$ and $55^{\circ} \mathrm{N}$, however, in Russia its range reaches further north up to $59^{\circ} \mathrm{N}$ (WILSON and REEDER 2005). The natural habitat for common hamsters is steppe and forest-steppe zones, although in Central and Western Europe, hamsters are associated almost exclusively with agricultural habitats (NECHAY 2000). Despite the extensive range and high population densities of this species up to the 1970 s, the decline of some Western European hamster populations was noticed (NeCHAY 2000). Over the last forty years, the range of the common hamster has contracted significantly not only in the west but in all European parts of its range (Weinhold 2008). In Belgium and France, the hamster is threatened with extinction, while in the Netherlands it is already extinct (NECHAY 2000). Currently, hamster populations in the Netherlands are the result of reintroductions. In Germany, where agriculture suffered from mass outbreaks of the hamsters in the second half of the $20^{\text {th }}$ century, the species range shrank significantly and became fragmented (Weidling and Stubbe 1988). Also in Poland, hamsters, which were formerly highly abundant, nowadays havelost most of their range (ZIOMEK and BANASZEK 2007). The same trend was described from the Czech Republic where hamsters retreated to the best habitats in the river valleys (TKADLEC et al. 2012). The causes of the progressive disappearance of the common hamster are not fully understood.

However, the common belief was that the species was not globally endangered as it was supposed to be quite abundant in the Eastern European and Asiatic part of its range (IUCN 2012). The decline in the inhabited area and numbers were presumably the problem of Western and Central European populations. However, recent studies on occurrence of the common hamster in Ukraine showed results similar to the rest of Europe. The species was rare in the western and northern part of the country or even extripated in Eastern and Southern Ukraine (Rusin et al. 2013). According to Rusin et al. (2013), there are currently only three main geographic areas occupied by the common hamster: NorthEastern Ukraine (Kiev, Chernigov, and Sumy oblasts), Western Ukraine (IvanoFrankovsk, Lvov, and Chernovtsy oblasts) and Crimea. To define the current state of the common hamster population in Ukraine, the authors used data from: zoological museums, available literature, personal reports of field zoologists and their own research carried out from 2004 to 2012 in 620 localities mainly in South-Eastern and North-Eastern Ukraine. When it comes to Western Ukraine, there was only one locality in Ivano-Frankovsk oblast which was confirmed by the authors. The other locations reported by RUSIN et al. (2013) were obtained from the outer sources mentioned above. In effect, the current state of hamster populations in Western Ukraine is still poorly recognized.

Therefore, the aim of our study was to determine the current range of the common hamster in Western Ukraine. For this purpose, we tried to verify the potential occurrence of the species in the places compiled by RUsin et al. (2013). 


\section{MATERIAL AND METHODS}

Information about possible common hamster sites in Western Ukraine was obtained from a previous study carried out by Rusin et al. (2013). According to this survey, the common hamster was found in 23 localities in Western Ukraine. The localities were grouped in 12 areas in 7 oblasts: Volyn, Lvov, Ternopol, Ivano-Frankovsk, Transcarpathians, Chernovtsy and Khmelnitskiy. The list of sources used by authors to elaborate the common hamster localities in Western Ukraine are given in Table 1, while detailed information is listed in Appendix 1. Only one locality in Halych, Ivano-Frankovsk oblast was confirmed by the authors.

Our research was carried out in late July and early August 2013. During the survey, we checked locations reported by Rusin et al. (2013) in six oblasts: Volyn, Lvov, Ternopol, Ivano-Frankovsk, Khmelnitskiy and Chernovtsy (Fig. 1).

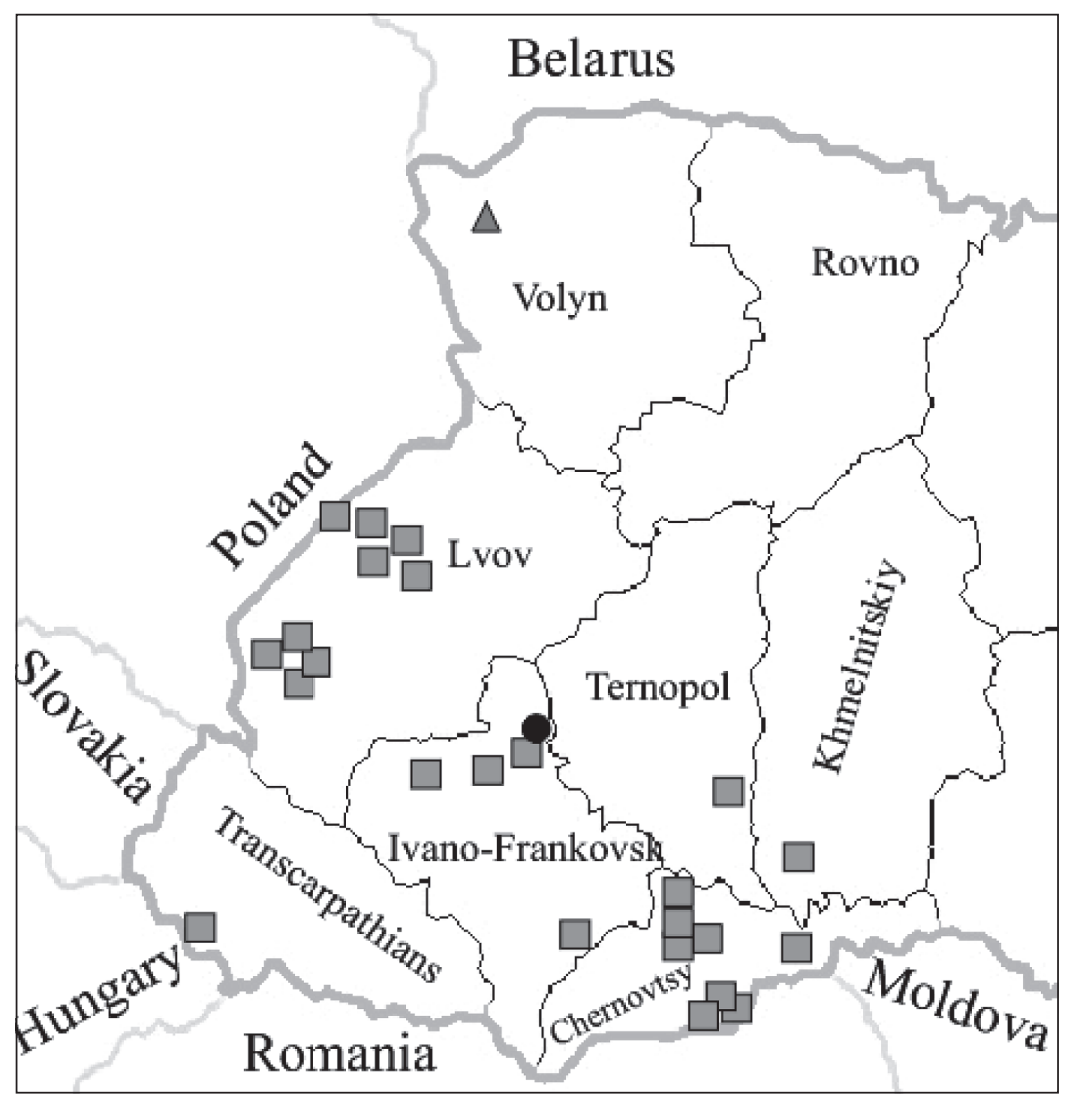

Fig. 1. Map of the common hamster localities in Ukraine obtained from Rusin et al. (2013). Filled circles - occupied localities confirmed by the authors, triangles and squares - occupied localities, known from literature or other sources, in 1990 2000 and 2001-2013 respectively. 


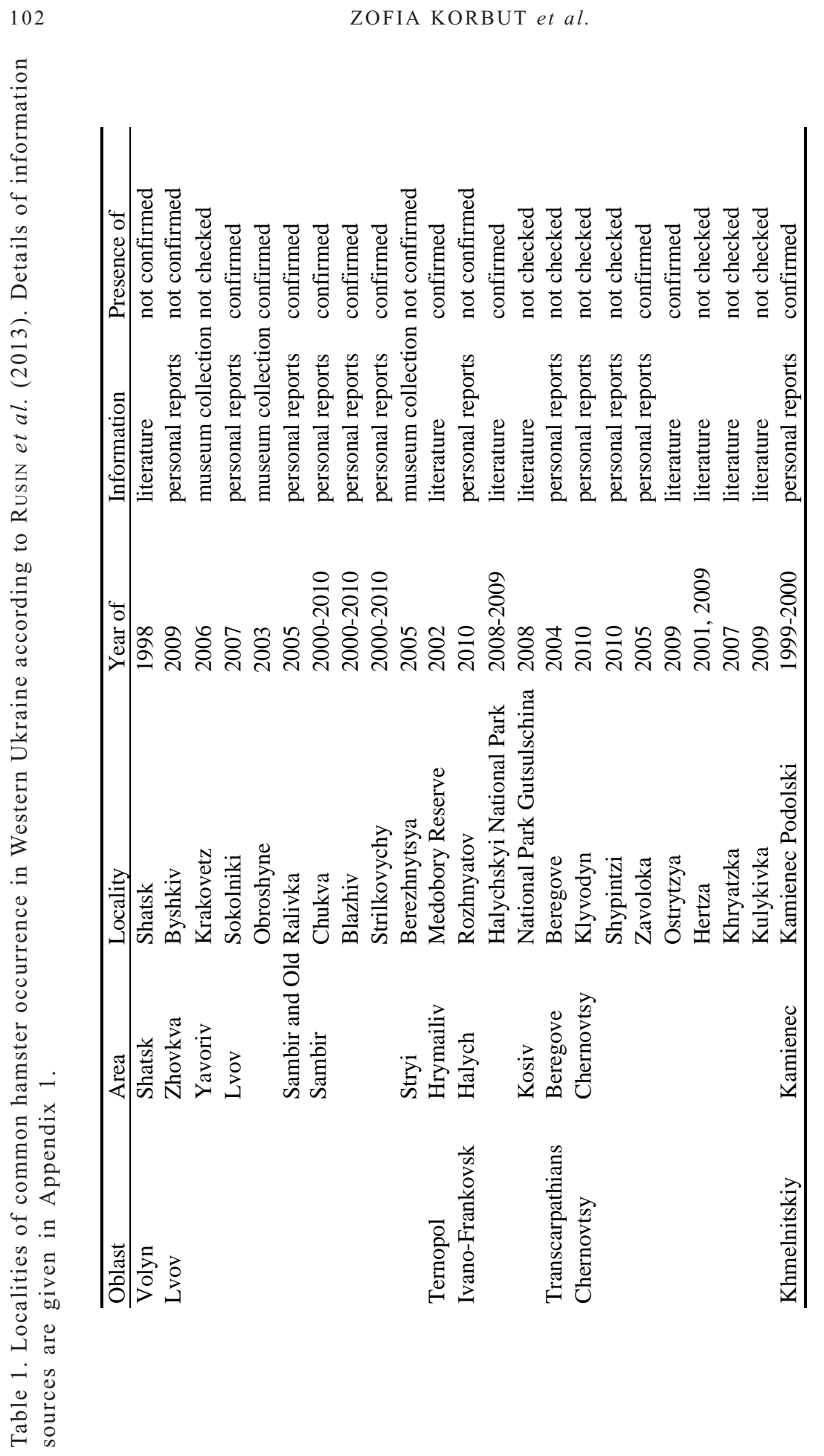


In order to verify the presence of hamsters, we searched mostly wheat fields for burrows and we set up hair traps (REINERs et al. 2011). Hair traps were usually exposed in one locality for one or two days and checked the next morning. If there were no hamster burrows in the checked locality and surrounding area we identified the location as uninhabited by hamsters. Following Rusin et al. (2013) we checked at least 20 ha before we decided that the locality was abandoned. The areas of checked fields were measured in Google Earth Pro (Sullivan 2009). The density based on the number of active burrows was assessed according to Nechay (2000): below 0.2 burrow per hectare the density was very low, $0.2-1$ low, 2-5 medium, 6-20 high and 21-50 very high.

Maps for the current study were created in QGIS 2.0.1-Dufoir using Natural Earth.

\section{RESULTS AND DISCUSSION}

In total, we confirmed eight areas of hamster occurrence from Rusin et al. (2013) located in Volyn, Lvov, Ternopol, Ivano-Frankovsk, Chernovtsy and Khmelnitskiy oblasts (Table 1 and 2, Fig. 2). Furthermore, we found one new locality located in Volyn oblast in Kopachivka near Lutsk (Fig. 2). The newly discovered locality turned out to be quite abundant in hamsters. The density amounted to 1.8 burrows/ha which represents medium density (Table 2). We were able to collect 6 hair samples from 21 traps set for one night. The quite high numbers of hamsters in this area are most probably associated with the traditional agriculture management and the presence of the gardens around each village. Such gardens are small fields of $0.5-2$ ha with a variety of crops: wheat, alfalfa, potatoes, beets and other vegetables which form suitable habitat for hamsters. We failed to confirm the presence of the common hamster in another locality in Volyn oblast reported by Gorban et al. (1998), in the region of Shatsk. This area is located in the Shatsky National Natural Park, created in order to protect the rare natural complexes in the region of Shatsk Lakes. The largest part of the Park is covered by Shatsk lake group, marshes and coniferous forests which are not normally inhabited by hamsters. It is definitely not a typical agricultural region and there are practically no cultivated fields, except some gardens in the villages which are situated on very sandy soils. Referring to Gorban et al. (1998), the common hamster still occurred in the Shatsk area in 1997. We consider this population to be extinct now because the presence of hamsters in such habitats could only result from dispersal of individuals from areas of high population density, most probably during mass outbreaks. Unfortunately, such conditions do not occur nowadays. To sum up, in the Volyn oblast, hamsters are still present in the Volyn Upland, whereas northern and central parts of that oblast, called Polesia, are most probably abandoned.

According to Rusin et al. (2013) research, there were five areas inhabited by hamsters in Lvov oblast. The first one, situated in Byshkiv in Zhovkivskyi district, was still inhabited by the species in 2009. During this study we failed 
to find any burrows in that area. The locality is situated in the West Bug Valley which is, in general, an area with high ground water level and intensively meliorated. During our research, the soils were very wet and even rainwater accumulated on the surface. We suppose that hamsters could not survive in such conditions. However, as the area is located in the middle of the PolishUkrainian range of the species (ZIOMEK and BANASZEK 2007, Rusin et al. 2013), it is possible that migrating animals could establish transient populations during drier years. We did not try to verify the presence of hamsters in the second point in Lvov oblast located near the Polish border in Krakovetz, Yavorivskyi district because there are data supporting multiple occurrences of the hamsters in that region on the Polish side, around the Torki village near Medyka (ZiomeK and BANASZEK 2007) or Radymno near Jarosław (BANASZEK and ZıomeK 2011). In the next two points reported by Rusin et al. (2013) in the south of Lvov (in Pustomyty district), located in the agglomeration of Lvov, we found no cultivated fields to check due to the high degree of urbanization of the area. Therefore, we could not confirm the locations so close to Lvov, but moving more to the southwest we found a population in the vicinity of Horodok (about $33 \mathrm{~km}$ southwest of Lvov). The entire area located near Horodok was not abundant in hamsters and was characterized by low density (Table 2). Six hair samples were collected during one night from 25 hair traps that were set up in that site. We also confirmed the presence of hamsters in several localities given by Rusin et al. (2013) situated between Sambir and Old Sambir. That region proved to be fairly abundant in hamsters. Density amounted in this case to 2.07 burrows/ha (medium density) and we collected 8 hair samples from 23 hair traps from two nights of trapping. The hamster localities occur in the valley of the river Dniester which provides convenient conditions for agriculture development. Important is the fact that besides the presence of the multi-acre fields, there is also traditional farming in that region. We did not confirm the presence of hamsters in the last point from the Lvov oblast, Berezhnytsya, located southeast of Stryi because of the lack of suitable habitats in that area. Due to the close proximity of Stryi city, the surrounding areas were either built up or were fallow land. However, similar to the points close to Lvov city, we cannot exclude the presence of hamsters in this area.

We were able to confirm the presence of hamsters in Ternopol oblast near Hrymailiv and Vikno. The density here reached 8.83 burrows/ha which is the highest density recorded during this study (Table 2). There were no large industrial fields present, only small $0.5-1$ ha ones, often in the vicinity of the home vegetable gardens which provide adequate habitat for hamsters. From the described area, 5 samples were collected from 31 hair traps during one night and an additional 2 were obtained from museum specimens from the Medobory Reserve collection.

In Ivano-Frankovsk oblast, the common hamster was reported from the Halychskyi National Park and this locality was confirmed by Rusin et al. (2013). We also confirmed the presence of hamsters in two localities in this area: 
Kinashiv near Halych and Nyzhnia Lypytsia near Rohatyn. The density in that region was maintained at a high level of 5.39 burrows/ha, however hamster hairs were present in 3 out of 16 hair traps only. It should be mentioned that the surrounding fields were mostly burned which may have contributed to lower activity of common hamsters. Another locality in Ivano-Frankovsk oblast was Rozhnyativ area, where the presence of hamsters was reported in 2010. However, we did not find any burrows in Dolyna and Rozhnyativ area. It is possible that the density of populations there is extremely low and we simply did not succeed in finding burrows in large monoculture fields that were present in that area. The region of Kosiv (the area of National Park Gutsulschina) has not been checked because the presence of hamsters is very doubtful there as the putative locality is situated in the mountains.

There is only one locality, given by Rusin et al. (2013), of common hamster occurrence in Khmelnitskiy oblast around Kamienec Podolski, as the species is reported from the Podilski Tovtry National Park. Our studies showed very low density in this area (Table 2). There was only 1 hair sample obtained from 12 hair traps set up in that region which is not surprising considering the fact that most of the local fields are multi-acre, industrial ones covered mainly with sunflowers, corn and sometimes wheat. According to Rusin et al. (2013) the increase of area used for sunflower and corn may be one of the main causes for the decline of common hamster populations in Ukraine, as this type of crop forms unsuitable habitats due to lack of long-term food and shelter for rodents and higher use of pesticides during cultivation.

In Chernovtsy oblast, Rusin et al. (2013) pointed out seven localities of the common hamster based on literature data and personal reports. During our research, we found large numbers of common hamster burrows in the Ostrytsya area. Taking into account the surface of checked fields, obtained density was medium. The agriculture in this area was again traditional with small fields and various crops. Points located south of Chernovtsy, close to the Romanian border were not checked in this study, however, considering the density of hamsters in the Ostrytsya area, similar agriculture system and lack of clear barriers for dispersal, the whole area around Chernovtsy may be considered inhabited by hamsters.

Regarding the Transcarpathian oblast, there is one locality given by Rusin et al. (2013) based on a personal report. This locality needs to be checked in the future as we were not able to travel there during this expedition. However, the Beregove site is situated in the Transcarpathian Lowland, which is a part of the Great Hungarian Plain where, at least in Slovakian part, hamsters are abundant (NeChAY 2000, BANASZEK, unpubl. data).

In conclusion, the common hamster in the western part of Ukraine occurs in the Volyn Upland and Podolia. High or medium densities of hamsters were found in Ternopol, Ivano-Frankovsk, Chernovtsy, Volyn oblasts and Sambir and Old Sambir in Lvov oblasts (Table 2). Low and very low densities were reported in some parts of Lvov oblast (Horodok) and in Khmelnitskiy oblast. The exist- 
ence of hamsters in Western Ukraine is supported by traditional agriculture management and, above all, the presence of small, private gardens which form ideal habitat conditions for this rodent. In the areas where traditional agriculture has been replaced by large-scale fields, the densities of hamsters are low, as mentioned above, or we were not able to confirm the presence of hamsters as in case of Dolyna and Rozhnyativ. Another threat for hamster populations is urbanization and the increase in area of fallow land. However, the presence of hamsters cannot be ruled out in urbanized areas of Lvov or Stryi as the hamster populations are repeatedly reported from the cities (SUROV and TovPINETZ 2007, Franceschini-Zink and Millesi 2008, Banaszek and Ziomek 2010).

As regards the contact between populations living in the territory of Western Ukraine and populations from neighboring countries, there is still contact with populations inhabiting the areas near the Polish border. Populations inhabiting the areas of Lvov oblast, located west of Sambir may remain connected with populations situated south of Przemyśl in Poland (Hermanowice and Nehrybka), as was suggested earlier by ZiomeK and BANAsZeK (2007). Such contact is also possible between populations inhabiting the aforementioned Krakovetz and populations living in the area of Jarosław, Radymno and Torki in Poland. Given the occurance in Volyn oblast, it is highly probable that populations inhabiting the area around Lutsk may be connected to populations from the Lublin Upland (Hrubieszów) in Poland. The possibilities of gene flow between the aformentioned populations will be confirmed through the genetic analyses of microsatellite markers. However, it is already clear that conservation of the species should be taken across the border with an agreement between Poland and Ukraine. Furthermore, the potential populations inhibiting Transcarpathian Lowland may be in contact with populations from Hungary, Slovakia and Romania, hence future studies are needed to confirm this.

The possibilities of gene flow between populations in Western Ukraine and South-Eastern Poland are additionally complicated by the presence of two phylogeographic lineages, Pannonia and E1 in Southeastern Poland (BAnaszeK et al. 2010). The Pannonia lineage in Poland inhabits the southern part of Małopolska Upland, Kraków-Częstochowska Upland, Upper Silesia and Sandomierz Basin. Whereas the E1 lineage comprises populations living in the Lublin Upland, Roztocze and the northern part of the Małopolska Upland (BANASzeK et al. 2010). The area that provides a barrier between two lineages was found to be in the Małopolska Upland (BANAszeK et al. 2012). According to BANASzeK et al. (2012), the habitat quality in the barrier area is too low for the survival of hamsters. The area is located in a region with a high percentage of woodland and composed of sandy soils that prevent the construction of stable, deep burrows which are needed by hamsters to survive the winter. Another area of probable contact between phylogeographic was formed in the past by the Solska Forest. The Solska Forest separates E1 populations inhabiting the Lublin Upland with Roztocze and Pannonia populations from the San River Valley (BANASZEK and Zıомек 2012). As it was discussed above, the populations from the Volyn 
Upland, Lutsk area may have contact with populations of E1 lineage while populations from the Lvov oblast remain connected with Pannonia populations in Poland (Fig. 2).

Unfortunately, there is only one source of information about the distribution of phylogeographic lineages in Western Ukraine. The common hamsters belonging to the E1 lineage occur in the area of Halych (BANASZEK et al. 2011) (Fig. 2). In such a case, it is very probable that in Ternopol, Ivano-Frankovsk, Chernovtsy and Khmelnitskiy oblasts the E1 lineage would be present. Putative

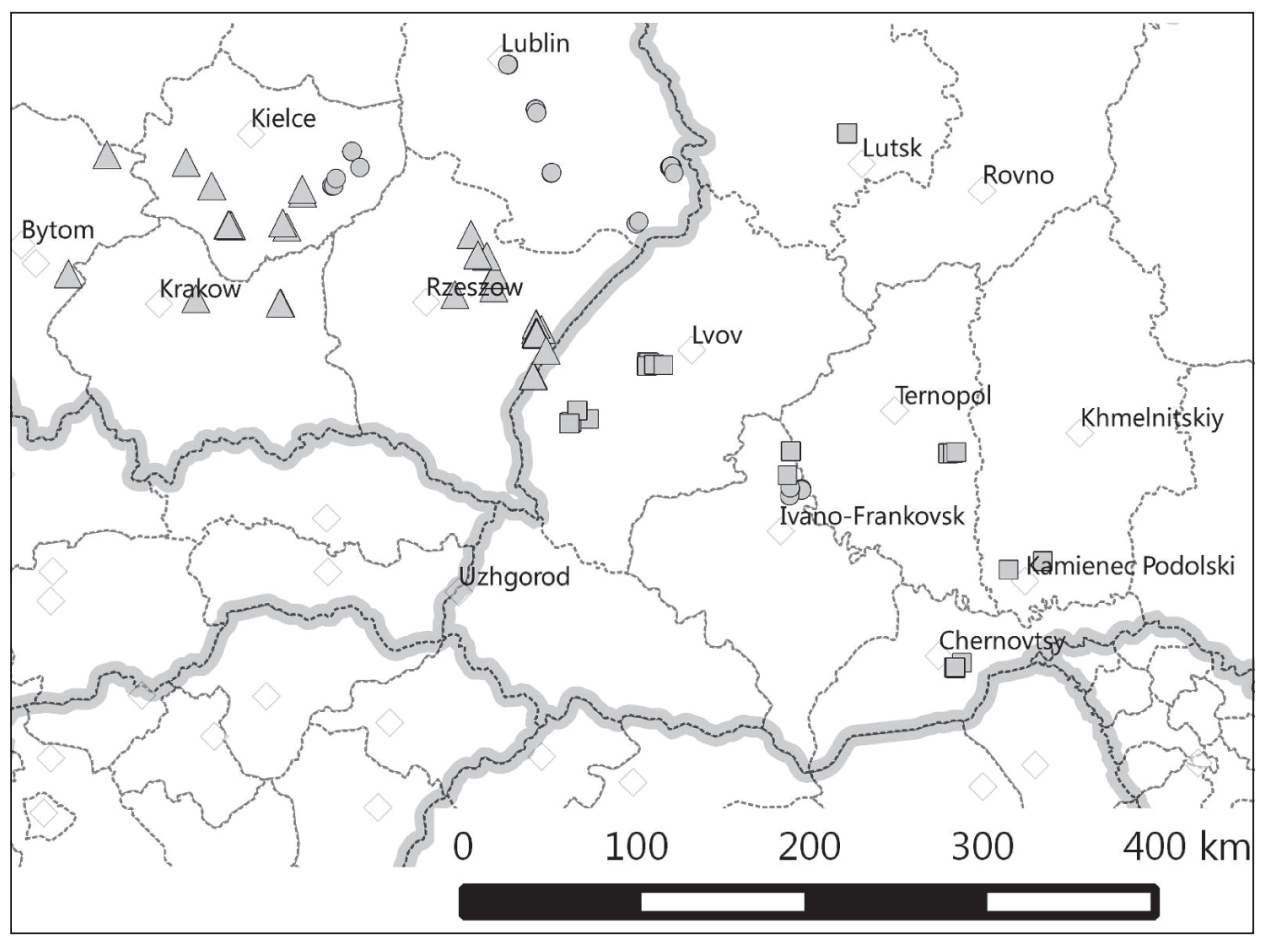

Fig. 2. The sampling localities of the common hamster (Cricetus cricetus) in southeastern Poland (BANASZeK et al. 2010, BAnAsZek and Ziomek 2011) and Western Ukraine. Triangles - the Pannonia lineage, circles - the E1 lineage, squares unknown lineage.

location of the contact area of E1 and Pannonia lineage would extend somewhere along the border between Lvov and Ternopol and then Ivano-Frankovsk oblasts. However, we are not able to indicate now any geographical barrier which could separate the lineages. To verify the distribution of the phylogeographic groups and areas of contact we will perform mitochondrial DNA analysis from hair samples collected during the field work. 
Table 2. The results of the field survey of the common hamster localities in western Ukraine with the population densities and number of collected samples.

\begin{tabular}{|c|c|c|c|c|}
\hline Oblast & Area & Locality & $\begin{array}{l}\text { Density } \\
\text { (burrows/ } \\
\text { hectar) }\end{array}$ & $\begin{array}{l}\text { Category } \\
\text { of density }\end{array}$ \\
\hline Volyn & Lutsk & Kopachivka & 1.81 & medium \\
\hline \multirow[t]{2}{*}{ Lvov } & Lvov & Horodok & 0.31 & low \\
\hline & $\begin{array}{l}\text { Sambir and } \\
\text { Old Sambir }\end{array}$ & $\begin{array}{l}\text { Sambir and } \\
\text { Old Sambir }\end{array}$ & 2.07 & medium \\
\hline Ternopol & Hrymailiv & $\begin{array}{l}\text { Medobory } \\
\text { Reserve }\end{array}$ & 8.83 & high \\
\hline \multirow[t]{2}{*}{ Ivano-Frankovsk } & Halych & Kinashiv & 5.39 & high \\
\hline & Rohatyn & $\begin{array}{l}\text { Nyzhnia } \\
\text { Lyptysia }\end{array}$ & & \\
\hline Chernovtsy & Chernovtsy & Ostrytsya & 2.48 & medium \\
\hline Khmelnitskiy & $\begin{array}{l}\text { Kamienec } \\
\text { Podolski }\end{array}$ & Shatava & 0.07 & very low \\
\hline
\end{tabular}

\section{Acknowledgements}

The authors wish to express their gratitude to the employees of the Medobory Reserve who kindly showed the fields inhabited by hamsters and offered samples from hamsters of the reserve collection. We also thank the employees of the Shatzk National Natural Park. Special thanks are extended to numerous local farmers, who kindly allowed inspection of their fields.

The work was financed by statutory research funds (Bst-146) to the Institute of Biology, University of Bialystok, Department of Genetics and Evolution.

\section{WYSTEPPOWANIE CHOMIKA EUROPEJSKIEGO (CRICETUS CRICETUS) W ZACHODNIEJ UKRAINIE.}

\section{STRESZCZENIE}

Celem niniejszych badań było określenie aktualnego rozmieszczenia populacji chomika europejskiego (Cricetus cricetus) na terenie zachodniej Ukrainy. W tym celu sprawdzono obszary dotychczas uważane za zamieszkane przez chomika, znane z dostępnej literatury, indywidualnych obserwacji i informacji pochodzących ze zbiorów muzealnych. Zgodnie z badaniami opublikowanymi przez Rusin i in. (2013), chomik Europejski występuje w 23 lokalizacjach zgrupowanych w 12 głównych obszarach położonych łącznie na terenie 7 obwodów zachodniej Ukrainy. Podczas tegorocznych badań potwierdzono obecność chomika europejskiego na terenie 8 z 12 obszarów opisanych przez Rusin i in. (2013) oraz znaleziono jedną nową 
lokalizację występowania tego gatunku. Największe zagęszczenie populacji chomika odnotowano w okolicy miejscowości Grzymałów, obwód Tarnopolski oraz miejscowości Halicz, obwód Ivano-Frankowski. Obszar zlokalizowany w sąsiedztwie Łucka w obwodzie Wołyńskim, Czerniowiec w obwodzie Czerniowieckim i pomiędzy Sambirem a Starym Sambirem w obwodzie Lwowskim charakteryzuje średnie zagęszczenie populacji chomika europejskiego. Niski i bardzo niski stopień zagęszczenia stwierdzono w populacjach zamieszkujących teren w okolicach Lwowa i Kamieńca Podolskiego położonego w obwodzie Chmielnickim. Dodatkowo w przedłożonej pracy omówione zostały warunki siedliskowe preferowane przez badany gatunek oraz możliwości kontaktu populacji zamieszkujących tereny przygranicze z populacjami chomika europejskiego z sąsiednich krajów.

\section{REFERENCES}

Banaszek A., Jadwiszczak K.A., Ratkiewicz M., Ziomek J., Neumann K. 2010: Population structure, colonization processes and barriers for dispersal in the common hamster Cricetus cricetus (L.) populations in Poland. J. Zool. Syst. Evol. Res., 48: 151-158.

Banaszek A., Ziomek J. 2010: The common hamster (Cricetus cricetus L.) population in the city of Lublin. Annales UMCS, Biologia, 65: 59-66.

Banaszek A., Zıomek J. 2011: The Common hamster, Cricetus cricetus (L.) populations in the Lower San River Valley. Zoologica Poloniae, 56: 49-58.

Banaszek A., Ziomek J., Rusin M., Balaz I., Tkadlec E., Neumann K. 2011: The phylogeography of the common hamster: the genetic diversity of the Ukrainian, Slovakian and Czech populations. 18th Meeting of the International Hamster Workgroup, Strasbourg, France.

Banaszek A., Ziomek J., Jadwiszczak K.A., Kaczyńska E., Mirski P. 2012: Identification of the barier to gene flow between phylogeographic lineages of the common hamster Cricetus cricetus. Acta Theriol., 57(3): 195-204.

Franceschini-Zink C., Millesi E. 2008: Reproductive performance in female common hamsters. Zoology, 111: 76-83.

Gorban I., Dykyi I., Srebrodolska E. 1998: What has happened with Cricetus cricetus in Ukraine? In: Stubbe M. \& Stubbe A. (eds.), Ecology and protection of the common hamster. Martin-Luther-Universität, Halle/Saale: 87-89.

IUCN. 2004: IUCN Red List of Threatened Species, IUCN-SSC (http://www.iucnredlist.org)

Nechay G. 2000: Status of hamsters: Cricetus cricetus, Cricetulus migratorius, Mesocricetus newtoni and other hamster species in Europe. Nature and Environment series 106, Council of Europe Publishing, Strasbourg.

Reiners T.E., Encarnaçăo J.A., Wolters W. 2011: An optimized hair trap for noninvasive genetic studies of small cryptic mammals. Eur. J. Wildl. Res., 57: 991-995.

Rusin M.Yu., Banaszek A., Mishta A.V. 2013: The common hamster (Cricetus cricetus) in Ukraine: evidence for population decline. Folia Zool., 62: 207-213.

Sullivan D. 2009: Google Earth Pro. EContent. 32(3): 16-18.

Surov A.V., Tovpinetz N. 2007: Population of common hamster in Simferopol (Ukraine): fast formation of synanthropic adaptations. 15th Meeting of the International Hamster Workgroup, Kerkrade, the Netherlands. 
Tkadlec E., Heroldová M., Víšková V., BednáŘ M., Zejda J. 2012: Distribution of the common hamster in the Czech Republic after 2000: retreating to optimum lowland habitats. Folia Zool., 61: 246-253.

Weidling A., Stubbe M. 1988: Zur aktuellen Verbreitung des Feldhamsters (Cricetus cricetus L.) in Deutschland. In: Stubbe M. \& Stubbe A. (eds.), Ecology and protection of the common hamster. Martin-Luther-Universität, Halle/Saale: $183-186$.

Weinhold U. 2008: Draft European action plan for the conservation of the common hamster (Cricetus cricetus L., 1758). Convention on the conservation of European wildlife and natural habitats, 28th Meeting of the Standing Committee, Strasbourg, France.

Wilson D.E., Reeder D.M. 2005: Mammal species of the World. A taxonomic and geographic reference, 3rd ed. Johns Hopkins University Press, Baltimore.

Ziomek J., Banaszek A. 2007: The common hamster, Cricetus cricetus in Poland: status and current range. Folia Zool., 56: 235-242.

Received 2013-11-15 


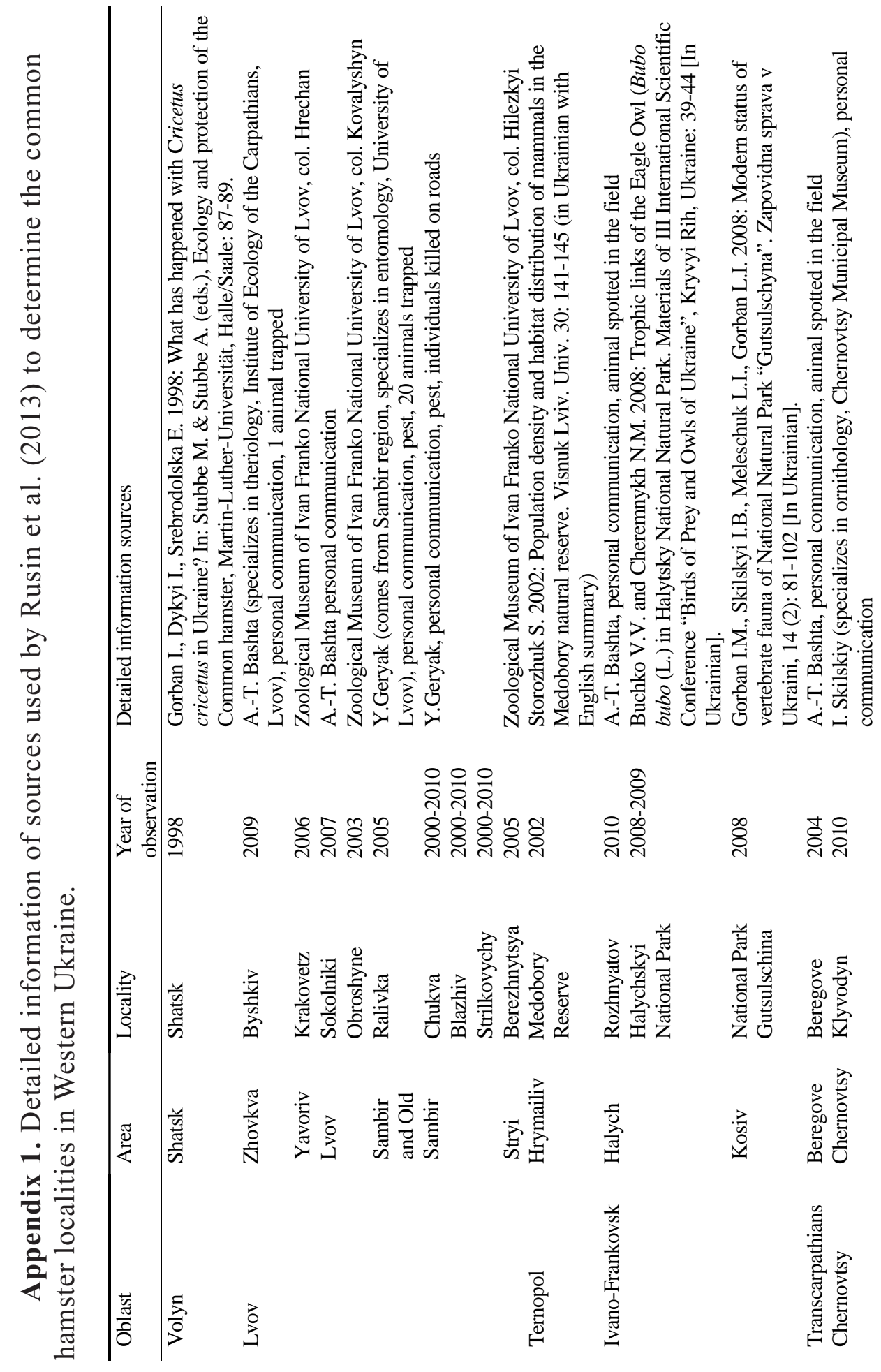




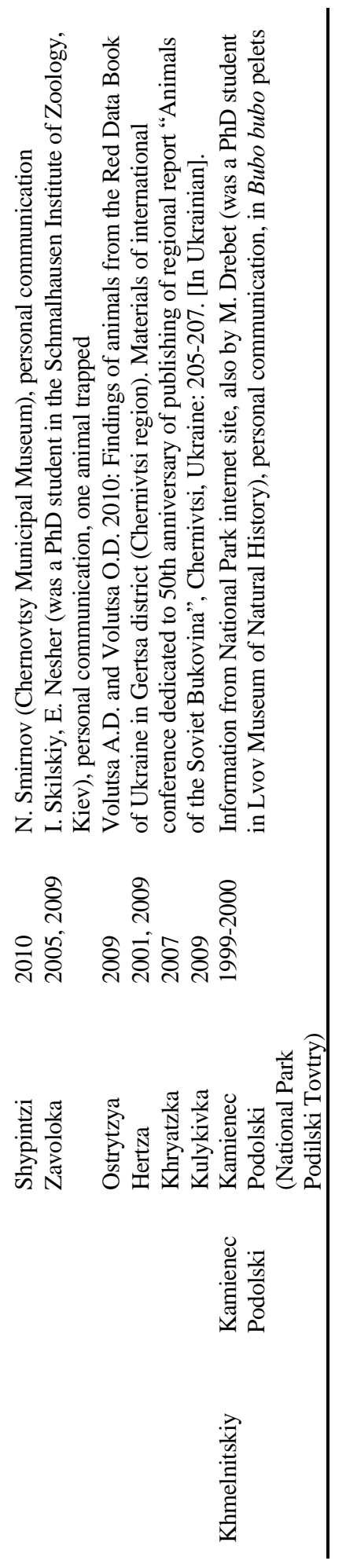

